\title{
The Solvency of the Jordanian Current Account
}

\author{
Mohammad Oqaily ${ }^{1} \&$ Mohammad Alawin ${ }^{2}$ \\ ${ }^{1}$ TheGeneral Budget Department, Amman, Jordan \\ ${ }^{2}$ Economics Department, Kuwait University, Kuwait \& Economics Department, the University of Jordan, Jordan \\ Correspondence: Mohammad Alawin, Economics Department, Kuwait University, Kuwait. E-mail: \\ m_alawin@hotmail.com
}

Received: February 12, 2019

Accepted: March 21, 2019

Online Published: April 30, 2019

doi:10.5539/mas.v13n5p78

URL: https://doi.org/10.5539/mas.v13n5p78

\begin{abstract}
This study measured the sustainability of the current account for the Jordanian economy during the period (19902017). Intertemporal Solvency Model has been used to know the ability of the government to pay its current obligations of future surpluses. The results of this study show that, in the long run, there is not enough solvency in the current account in Jordan. Thus, the economy of Jordan faces a significant challenge in the future. This challenge comes from the lack of adequate sources for funding the accumulated obligations. Accordingly, the study recommends that the government should adopt economic policies that help reduce the current account deficit by importing the capital goods necessary to support the production and export sectors. These policies will improve the sustainability of the current account.
\end{abstract}

Keywords: sustainability, solvency, current account, exports, imports, Jordan

\section{Introduction}

Jordan is a small developing country that has limited resources and follows an open economic policy. Jordan relies heavily on imports to stimulate the development process. Its exports are limited and are concentrated in some extractive industries, such as phosphates, potash, and some seasonal agricultural products. Its foreign markets are limited and are heavily influenced by global and regional political conditions. These conditions lead to imbalances in Jordan's trade balance and, thus, in its current account.

The current account of the Jordanian economy has suffered during the last three decades from an average deficit of about $-8 \%$. The current account deficit is a major problem for many countries, because of the leakage of income abroad and the depletion of reserves. The deficit also has negative effects on many economic activities.

The purpose of this study is to determine the extent to which the economy is able to generate future financial surpluses sufficient to pay its current liabilities, resulting from the current account deficit. Generating financial surpluses may come from using imports effectively and efficiently to stimulate the production process, to support the export sector, and gradually, to improve the trade balance to correct the current account imbalances.

Accordingly, this study was designed to measure the current account's sustainability and to determine the extent of the Jordanian economy's ability to meet its financial obligations during the period 1990-2017. To achieve this objective, the study will use both descriptive and econometric methods.

The remainder of this study is divided into the following sections. Part 2 discusses previous studies; part 3 discusses the theoretical framework; and part 4 examines the most prominent developments in the Jordanian economy and the current account. The fifth and sixth parts cover the methodology and the empirical results, respectively. Finally, the seventh part includes conclusions and recommendations for the study.

\section{Literature Review}

Several previous studies have examined the degree of solvency of the current account using different methods, including the Intertemporal Solvency Model (ISM). The ISM measures the relationship between exports and imports. This model has been used intensively on many economies, whether developing or developed countries, to determine if these countries can meet the solvency conditions in the current account.

AbdulWadud, Rahman, \& Chowdhury (2015) studied the current account for Bangladesh. Fountas\& Wu (1999) and Husted (1992) examined the case of the United States. Leachman\& Thorpe (1998) researched the current 
account for Australia. Apergis, Katrakilidis, \&Tabakis (2000) studied the current account solvency for Greece. Arize (2002) researched the current account solvency for 50 developed and developing countries, Baharumshah (2002) examined the case for Malaysia and Thailand, and Binatli\&Sohrabji (2009) studied Turkey's current account. Shastri, Giri, \&Mohapatra (2018) examined the current accounts for South Asian countries. Some of these studies the current account was solvent, meaning that the existing deficit in the current account balance can be paid from the future surplus. On the other hand, some studies found that the current account balance is in a weak position.

To the best of our knowledge, no study has examined the current account solvency in Jordan. Therefore, this study will expand the literature by adding Jordan to the countries that have already had their current account status determined.

\section{Theoretical Framework}

The current account is one of the main indicators for measuring the performance of the external sector. Current account imbalances affect the local economy and may result in significant changes in the exchange rate. These imbalances are seen also as indicators of the weakness of economic policies. Maintaining a balance in the external sector in an open economy is important but extremely difficult. According to Krugman, Obstfeld, \&Melitz (2018), the external balance is achieved when the ideal level of the current account balance is reached. This level means that the current account of a country is not in a large deficit situation in which the country will be unable to meet its future external obligations.

The current account plays an essential role in producing an efficient and effective economy. The current account has a close relationship with investment, national savings, and financial balance. In addition, the current account has important effects on economic growth.

There is no direct and easy rule to measure the degree of solvency of the current account. However, there are two widely used methods to test the solvency. According to the Benchmark Approach, there is a current account insolvency if the ratio of current account deficit to GDP exceeds $5 \%$. The current account solvency is inversely proportional to the ratio of net international debt to GDP; the higher this ratio the lower the current account solvency ratio (AbdulWadudet al., 2015). The Intertemporal Approach includes a model of the intertemporal sustainability of the current account; this approach was developed by Hakkio\&Rush (1991) and Husted (1992). The ISM examines the relationship between inflows and outflows to the current account in the long term. This requires that exports of goods and services (inflows) be integrated with imports of goods and services (outflows), and the integration between these two series implies current account solvency.

The theoretical model for assessing the current account solvency assumes that the value of borrowing from the global market in an open economy must equal the present value of the future current account surplus. The current account solvency means that the current deficit can be paid from the future surplus. The model starts with the individual budget constraint and it can be extended to the whole economy.

The community budget constraint for the current period according to Hakkio\&Rush (1991) and Husted (1992) is:

$$
C_{t}=Y_{t}+B_{t}-I_{t}-(1+r) B_{t-1}
$$

where $C$ is consumption. $Y$ is production, $B$ is net international borrowing, $I$ is investment expenditure, and $r$ is world interest rate. The term $(1+r) B_{t-1}$ is the size of the basic debt of a society, which equals to the external debt of the country, and $t$ is the time period.

The trade deficit reflects the surplus of income over consumption and investment expenditure. This relationship can be represented by the following equation:

$$
T B_{t}=X_{t}-M_{t}=Y_{t}-C_{t}-I_{t}
$$

$T B$ is the trade balance that represents income minus consumption and investment. $X$ is exports, and $M$ is imports. As long as equation (2) is true at any given time period, the budget constraint of the society accumulates from period to period forming the time budget of the economy (Binatli\&Sohrabji, 2009). This can be represented as:

$$
B_{t}=\sum_{i=1}^{\infty} \rho\left(M_{t}-X_{t}\right)+\rho(1+r) B_{t-1}
$$

where $\rho$ is the coefficient of discount.

If the current value of the country's basic debt, $(1+r) B_{t-1}$, is zero, then the amounts currently borrowed or lent by the government from the international market $\left(B_{t}\right)$ are equal to the present value of future trade surplus or deficit, 
respectively. If $B_{t}$ is positive, then the present value of imports is greater than the present value of exports. Therefore, the current borrowings for financing imports cannot be repaid in the future. However, if $B_{t}$ is negative, the present value of exports is higher than the present value of imports. Therefore, the government can finance its external debt in the future.

Husted (1992) held several assumptions, including that the global interest rate is stable. By performing some mathematical operations, we reach the following equation:

$$
M_{t}+(1+r) B_{t-1}=X_{t}+B_{t}
$$

After performing some mathematical operations and adding the residue limit, the following regression model is obtained (Perera\&Varma, 2008):

$$
X_{t}=\alpha+\beta M_{t}+U_{t}
$$

where $U$ is the error term, and $\alpha$ and $\beta$ are parameters. Equation 5 is the empirical model that will be used to measure the current account solvency in the Jordanian economy.

\section{The Jordanian Economy and the Current Account}

The current account is of great interest to any economy; it represents a record of the flows of goods and services between the local economy and the outside world. It is also the most important part of the balance of payments. Imbalances in the current account lead to imbalances in other economic variables.

\subsection{Analysis of the Current Account and Its Components During the Entire Period, 1990-2017}

By analyzing changes in current account items during the study period, as shown in Table (1), several points can be observed. The current account in Jordan achieved remarkable development during the period from 1990-2017, increasing from a deficit of JD (402.5) million in 1990 to JD (3053.7) million in 2017. The average deficit during the study period was (977.2) million dinar. As a percentage of GDP, the current account deficit declined from 14.6\% in 1990 to about $10.6 \%$ in 2014; it peaked at $18 \%$ in 2005 .

The study period can be divided according to the current account development in Jordan to four main blocks. The first period, 1990-1992, witnessed a rise in the current account deficit, which increased from (402.5) million dinars in 1990 to (587.7) million dinars in 1992. At this time, Jordan was affected by the events of the Gulf crisis and the consequent return of tens of thousands of Jordanians living in the Gulf. Jordan also experienced the reduction of remittances from abroad and an increase in imports during the period.

In the second period, 1993-2004, the current account improved noticeably. The current account deficit began to decline, the deficit narrowed and the current account turned into a surplus. The current account deficit decreased from (446.4) million in 1993 to 157.4 in 1996. The current account started with a surplus of JD 849.8 million in 2003 and decreased to JD 27.7 million in 2004. During this period, Jordan adopted an economic reform program in cooperation with the International Monetary Fund and the World Bank (1992-1998), a national program for economic reform (1999-2001), and a five-year plan (1999-2003) aimed at a number of objectives. The five-year plan objectives included: controlling the current account deficit and the balance of payments, increasing workers' remittances and foreign aid, and improving exports.

During the third period, 2005-2012, the current account deficit rose relatively high, from (1610.6) million JD in 2005 to (3345.3) million dinar in 2012, due to the war on Iraq in 2003, the global crisis in 2008-9, the increases in international oil prices, and the impact of political and economic conditions that accompanied the Arab Spring from 2010 to 2012. In the Arab Spring, exports declined due to the closure of most export markets for Jordanian products. Also at this time, the tourism sector declined and transportation and shipping roads moved.

The fourth period, 2013-2017, witnessed remarkable fluctuations in the current account deficit. The current account declined from (2448) million dinars in 2013 to about (1851.7) million dinars in 2014, then rose to (3053.7) in 2017. This period witnessed an increase in current transfers; the rise was in foreign aid and in the compensation of the Syrian refuge support to the Kingdom. The huge jump at the end of the period was attributed to the enormous jump in imports.

Trade balance is in a permanent deficit, while current transfers are in a permanent surplus. On the other hand, the income account and the services account have both deficit and surplus figures. As a result, the current account in Jordan suffers from a deficit during most of the study period. Out of 29 years, there were seven years of surpluses, only one of which was a significant surplus of 849 million JD recorded in 2003. That surplus was attributed to a significant rise in the transfers due to the increase in foreign aid. 
The permanent deficit in the trade balance was attributed to the weak production base, forcing Jordan to provide a large part of capital, intermediate, and consumer goods through imports. In addition, the diversification of the Jordanian exports is weak. Exports were concentrated in fields like phosphates, potash, and some agricultural products. Other reasons for the deficit were the high global oil prices and the discontinued supply of Egyptian gas used in the generation of electricity. Finally, Jordan's exports were usually negatively affected by the political circumstances experienced in the region, such as the Gulf War and the Arab revolutions.

A constant surplus was recorded in the current transfers account, during the whole study period. That was mainly a result of the increase in net remittances, foreign aid, and international transfers, such as the support to the Syrian asylum process. There is a clear fluctuation in the current transfers account from one period to another depending on the political and economic conditions experienced by the region and the world.

The services account witnessed a surplus in most years of the study, except for the period 2000-2005. However, the deficits in those years were not large values. The surplus in the services account was supported mainly by the improvement in the travel and government services items.

The current account improved significantly, during the period 1993-2004. At that time, Jordan adopted two economic reform programs. This development indicates the importance of these programs in improving the current account position.

The current transfers, workers' remittances and foreign aid, are important in reducing the current account deficit. However, it will be difficult to rely completely on this item to correct current account imbalances, since it is widely affected by external and regional conditions.

Figure (1) shows the development of the current account and its components during the period 1990-2017. The figure implies that the trade balance and the current transfers have the most effect on the movements of balance of payments.

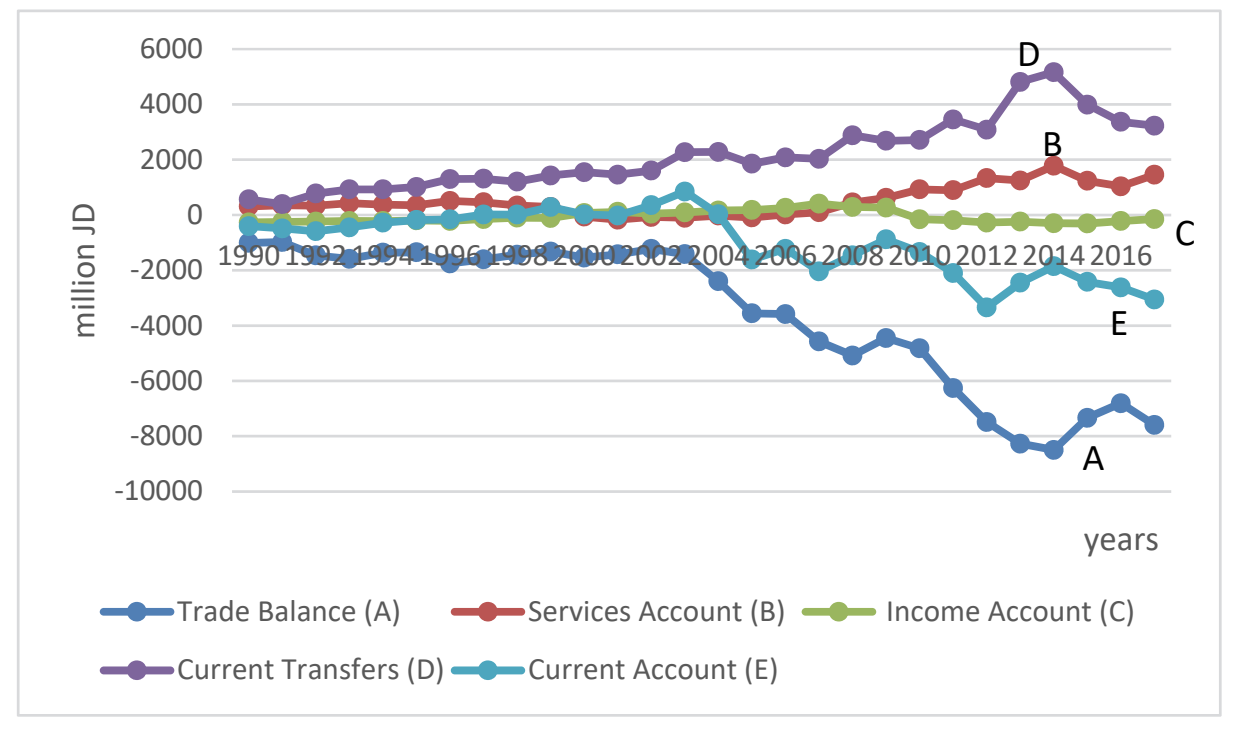

Figure 1. Current account and its components (1990-2017)

\subsection{Evolution of Exports and Imports}

The relationship between imports and exports gives an important indicator of the solvency of the current account. This relationship reflects the extent to which the country is able to pay its current liabilities from the future surplus. The intuition behind this is that imports are a leakage of income that could be efficiently and effectively used to generate exports and then reduce the current account deficit.

To maintain the sustainability or the solvency of the current account, the focus should be on importing capital goods needed to support local industries and expand the production base for two main purposes. The first is to produce alternative goods for imports and to meet the needs of the local market. The second is to support export growth. Either case reduces the current account deficit, increases GDP, stimulates the economic growth rate, and, thus, generates future surplus to repay the existing deficit in the current account. 
If the opposite happens, this will lead to an accumulation of current account deficits, depletion of foreign reserves, worsening indebtedness, and huge future financial obligations. These descriptions might be consistent with the current situation of the Jordanian economy. It suffers from a near-chronic deficit in the current account, a large and unprecedented accumulation of indebtedness, and a weakness in the productive base that does not help to meet the future obligations of the Jordanian economy.

In recent years, exports have failed to keep pace with the development in imports, most of which are for consumption purposes. For example, the proportion of imports of capital goods in 2014 amounted to only $12.6 \%$ of the total imports, and these imports concentrated in machinery, equipment, transport, and spare parts. On the hand, the proportion of imports of durable and nondurable consumer goods accounts for $26.9 \%$ that year. Finally, imports of raw materials and intermediate goods, including crude oil, reached the highest percentage of $58.9 \%$. Figure (2) shows the relationship between imports and exports during the period 1990-2017.

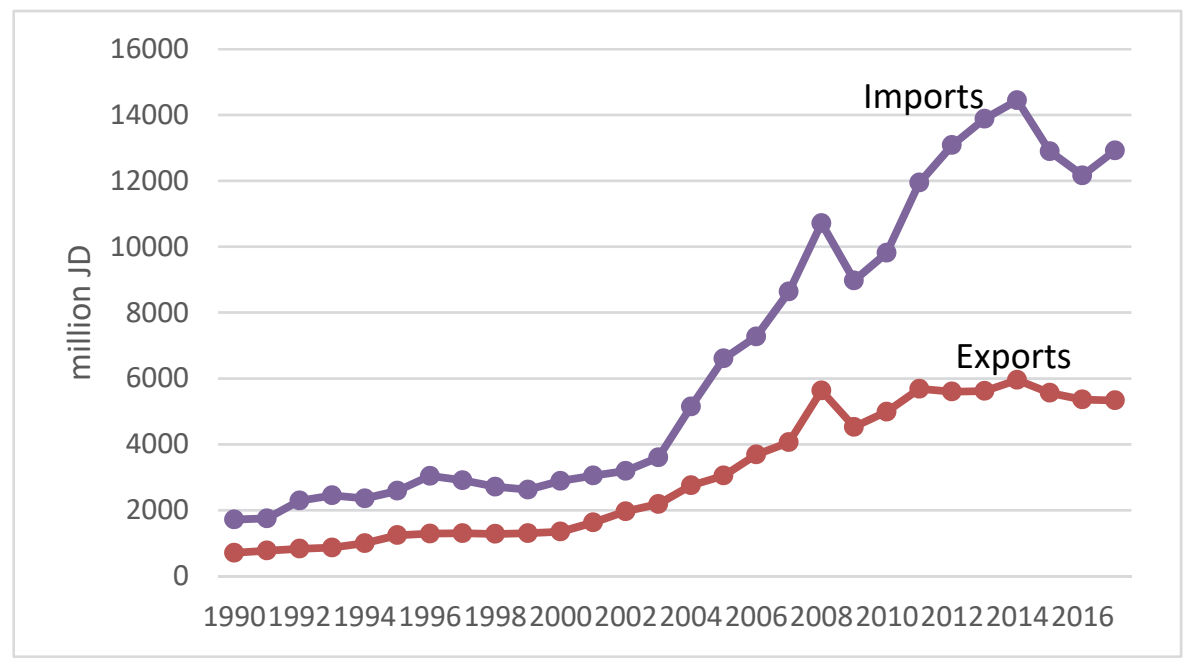

Figure 2. Imports and Exports during the Period (1990-2017)

The development of imports and exports during the period 1990-2017 are shown in Table (3). Exports increased from 706.1 million JD in 1990 to 5333.1 million JD in 2017, and recorded the lowest value in 1990 and the highest value in 2014. The average value for exports during the study period was 3054 million JD, and the average export growth was about $8.5 \%$ during that time. Exports recorded the highest growth rate in 2008, reaching 38.6\%, while the lowest growth rate was in 2009 at $-19.7 \%$.

Imports increased from 1714.7 million JD in 1990 to 12926.3 million JD in 2017, and recorded the lowest value in 1990 and the highest value in 2014. The average value of imports during the study period was 6632 million JD, and the average growth rate of imports was $9.7 \%$ during the period of study. Imports recorded the highest growth rate in 2004 reaching 43\%, while the lowest growth rate was in 2009 at $-16.3 \%$.

There is a direct relationship between imports and exports during the period of study. This positive or direct relationship was witnessed during the whole study period, except in 1994, 1999, and 2012. Applying econometric analysis, this paper will confirm the nature of the relationship between imports and exports to determine the level of solvency of the current account in the Jordanian economy.

\section{The Methodology and the Econometric Analysis}

This section measures the current account solvency in the Jordanian economy. This study uses the econometric model in equation 5 by Husted (1992). After getting the real values and the natural logarithm of the variables, the model becomes:

$$
\operatorname{LnRX} X_{t}=\alpha+\beta \operatorname{LnR} M_{t}+U_{t}
$$

$L n R X$ is the natural logarithm of real exports, $L n R M$ is the natural logarithm of real imports, $U$ is the error term, $\alpha$ and $\beta$ are the coefficients of the model, and $t$ is time period.

The logarithmic form of the variables was used to eliminate the problem of the trend in the data. The graphs of the variables, presented in the appendix, showed a general trend in the data, and therefore the instability of the variance or mean. Thus, the linear formula of the relationship may produce misleading results. 
The parameter $(\beta)$ represents the relationship between imports and exports and measures the solvency of the current account. If the relationship between imports and exports is not statistically significant, or if the value of $\beta$ is less than or equal to zero, then there is no current account solvency. However, if the relationship is strong and statistically significant, and if the value of $(\beta)$ is equal to or greater than one, then there is current account solvency. This means that the economy is able to generate sufficient surpluses in the future to cover the current account deficit.

Finally, if the relationship between imports and exports is statistically significant but weak, and if the value of $\beta$ is greater than zero and less than one, it means that although imports contribute to export growth, the current account status remains vulnerable. In other words, the relationship is not strong enough to generate enough surplus in the future to pay the ongoing current account deficit.

\subsection{Statistical Tests}

To achieve the objectives of the study, the time series stationarity test will be used, since most of the time series data of the economic variables suffer from a unit root problem. Therefore, the immediate use of the ordinary least square (OLS) method might give spurious regression results despite statistical significance (Chermza\&Deadman, 1992)

The Augmented Dickey-Fuller (ADF) test is used to test the stationarity of the time series. In this test, the Akaika Information Criterion or the Schwarz Bayesian Criterion is used to determine the appropriate lag. If the results of the ADF test show that the time series is stationary at the level, (I)0, then the OLS method can be used to estimate the parameters of the model. However, if the time series is non-stationary at the level, then the test is repeated after taking the first difference. If the series becomes stationary, then the time series is integrated of the first order, I(1). If the series is still non-stationary, we repeat the test after taking the second difference. If it is stationary, it means that the series is integrated in the second order (Gujarati, 2010).

If the variables were found non-stationary in their levels and become stationary at their differences, this refers to the possibility of a cointegration relationship between variables in the long term (Engle \& Granger, 1987). To examine the relationship in the long term, Johansen's test will be used to test for a possibility of a cointegration relationship between the variables (Granger, 1986). The Johansen technique includes two tests: the trace and the maximum eigenvalue tests. If a long-term relationship is reached, then the parameters are interpreted as long-term elasticities.

\section{The Empirical Results}

\subsection{Data Stationarity Test}

It is important before we apply equation 6, which measures the current account solvency in the Jordanian economy, we perform the ADF test. The ADF test was performed with an intercept and a trend to confirm the stationarity of the data. The results of this test, as shown in Table 3, indicate that the variables of exports and imports at their levels suffer a problem of unit root.

When applying the ADF test on the first difference, as shown in Table 4, it was found that the two variables become stationary. That is, the variables are integrated of order 1; I(1).

Because the variables are stationary on the first difference, the use of the OLS method involves the risk that the inability to eliminate the specific trend will affect the estimation results. However, the stochastic trend can be eliminated only after taking the first difference. So, we have to apply the analysis of cointegration to analyze the relationship in the long term.

\subsection{The Results of the Cointegration Test}

Because the data are stationary on the first difference, this indicates a possibility of a cointegrated relationship between the variables in the long run. The results of the cointegration test on equation 6 using the Johansen method are shown in Table 5. The results indicate that the null hypothesis of no cointegration was rejected, where the calculated value was greater than the critical value at the level of significance of $5 \%$. However, the hypothesis of a single vector could not be rejected at a $5 \%$ significance level. These results give the evidence of the existence of a long run equilibrium relationship between the variables (Granger, 1986). The results of the cointegrated vector are as follows:

$$
\operatorname{LnRX}=1.28-1.15 \operatorname{LnRM}
$$




$$
R^{2}=0.72 \quad F=1.65 \quad \text { D. } W=1.92
$$

The results of the cointegrated vector indicate that the impact of imports on exports is negative in the long run. Specifically, the increase in imports by $1 \%$ leads to a decrease in exports by $1.15 \%$ in the long term. The error correction model is not used to analyze the relationship in the short term since the current account solvency is measured by the long-term relationship. Since the coefficient of imports is less than $0,-1.15 \%$, then this indicates that there is no current account solvency in Jordan. In this sense, the present obligations of the economy cannot be paid by the future surplus, or the existing deficit in the current account cannot be covered from future surplus.

\section{Conclusion}

The objective of this study is to measure the current account solvency of the Jordanian economy during the period 1990-2017, i.e. to know the extent to which the economy is able to meet its current liabilities from its future surplus. Based on the empirical results, it was found that the effect of imports on exports in the Jordanian economy is negative in the long term. One possible reason for that relationship is that imports go mostly to consumer goods. This is a leakage of income abroad, leading to a decline in capital necessary for the development of productive sectors, including the export sector. In addition, imports lead to the provision of sufficient consumer goods to the local market at a lower cost than their domestic production. This is often the case in developing countries, leading to a decrease in local production and the inability to supply these commodities locally.

The average ratio of the current account deficit to GDP during the study period was about $6.7 \%$. This indicates that there is no solvency in the current account balance according to the benchmark approach. This approach holds that if the current account deficit to GDP exceeds $5 \%$, then there would be no solvency in the current account balance. This result confirms the result obtained using the ISM econometric analysis.

In light of these results, the study recommends adopting strict economic plans to reduce the current account deficit. These plans should put the focus on importing capital goods needed to support the production process, reduce imports of consumer goods, and support the export sector to enhance current account solvency.

\section{References}

AbdulWadud, M., Rahman, S., \& Chowdhury, M. (2015). Sustainability of the Current Account in Bangladesh: an International and Cointegration Analysis. The Journal of Developing Areas, 49(1), 353-364. https://doi.org/10.1353/jda.2015.0019

Apergis, N., Katrakilidis, K., \& Tabakis, N. (2000). Current Account Deficit Sustainability: The case of Greece. Applied Economics Letters, 7(9), 599-603. https://doi.org/10.1080/13504850050059087

Arize, A. (2002). Imports and exports in 50 countries: tests of cointegration and structural breaks, International Review of Economics and Finance, 11(1), 101-115. https://doi.org/10.15640/jibe.v4n1a6

Baharumshah, A. (2002). The Effect of Exchange Rate on Bilateral Trade Balance: New Evidence from Malaysia and Thailand. Asian Economic Journal, 15(3), 291-312. https://doi.org/10.1111/1467-8381.00135

Binatli, A., \& Sohrabji, N. (2009). Intertemporal Solvency of Turkey's Current Account.Izmir University of Economics Working Papers, No. 0805.

Chermza, W., \& Deadman, P. (1992). Newdirection in Econometrics. Practices, Edward Elgar, England.

Engle, R., \& Granger C. (1987). Cointegration and Error Correction: Representation, Estimation and Testing. Econometrica, 55(2), 251-276. http://doi.org/10.2307/1913236

Fountas, S., \& Wu, J. (1999). Are the U.S. Current Account Deficits Really Sustainable? International Economic Journal, 13(3), 51-58. https://doi.org/10.1080/10168739900000004

Granger, C. (1986). Development in the Study of Cointegration Economic Variables. Oxford Bulletin of Economics and Statistics, 48(3), 213-228. https://doi.org/10.1111/j.1468-0084.1986.mp48003002.x

Gujarati, D. (2010). Basic Econometrics (5th ed.). New York, NY:McGraw-Hill.

Hakkio, S., \& Rush, M. (1991). Is the Budget Deficit Too Large? Economic Inquiry, 29(3), 429-445. https://doi.org/10.1111/j.1465-7295.1991.tb00837.x

Husted, S. (1992). The Emerging U.S. Current Account Deficit in the 1980s: A cointegration Analysis. Review of Economics and Statistics, 74(1), 159-166.https://doi.org/10.2307/2109554

Krugman, P., Obstfeld, M., \& Melitz, M. (2018). International Economics: Theory and Policy (11th ed.). New 
York, NY: Pearson Education.

Leachman, L., \& Thorpe, M. (1998). Intertemporal Solvency in the Small Open Economy of Australia. The Economic Record, 74(226), 231-242. https://doi.org/10.1111/j.1475-4932.1998.tb01921.x

Perera, N., \& Varma, R. (2008). An Empirical Analysis of Sustainability of Trade Deficit: Evidence from Sri Lanka. International Journal of Applied Econometrics and Quantitative Studies, 5(1), 79-92.

Shastri, S., Giri, A., \& Mohapatra, G. (2018). Testing the Sustainability of Current Accounts for Major South Asian Economies: A Panel Data Approach.South Asia Economic Journal, 19(1), 1-21. https://doi.org/10.1177/1391561418761064

\section{The Appendix}

Table 1. Current account development (1990-2017) (million JD)

\begin{tabular}{|c|c|c|c|c|c|c|c|}
\hline Year & $\begin{array}{l}\text { Trade } \\
\text { Balance } \\
\text { (A) }\end{array}$ & $\begin{array}{l}\text { Services } \\
\text { Account } \\
\text { (B) }\end{array}$ & $\begin{array}{l}\text { Income } \\
\text { Account } \\
\text { (C) }\end{array}$ & $\begin{array}{l}\text { Current } \\
\text { Transfers } \\
\text { (D) }\end{array}$ & $\begin{array}{l}\text { Current } \\
\text { Account } \\
(E=A+ \\
B+C+D)\end{array}$ & GDP & $\begin{array}{l}\text { Current } \\
\text { Account } \\
\text { GDP } \\
(\%)\end{array}$ \\
\hline 1990 & -1008.6 & 308.6 & -267.2 & 564.7 & -402.5 & 2760.9 & -0.146 \\
\hline 1991 & -979.5 & 351 & -246.8 & 390.9 & -484.4 & 2958 & -0.164 \\
\hline 1992 & -1461.7 & 336 & -236.6 & 774.6 & -587.7 & 3610.5 & -0.163 \\
\hline 1993 & -1585.2 & 426.9 & -214.8 & 926.7 & -446.4 & 3884.2 & -0.115 \\
\hline 1994 & -1362.4 & 377 & -220.1 & 926.3 & -279.2 & 4357.4 & -0.064 \\
\hline 1995 & -1347.1 & 350.4 & -195.1 & 1012 & -179.8 & 4714.7 & -0.038 \\
\hline 1996 & -1753.4 & 510.7 & -213.4 & 1298.7 & -157.4 & 4911.3 & -0.032 \\
\hline 1997 & -1605.1 & 461.2 & -148 & 1312.7 & 20.8 & 5137.4 & 0.004 \\
\hline 1998 & -1434.5 & 341.5 & -97.9 & 1206.4 & 15.5 & 5609.9 & 0.003 \\
\hline 1999 & -1323.7 & 291.2 & -109.6 & 1429.2 & 287.1 & 5778.1 & 0.05 \\
\hline 2000 & -1541.7 & -58.4 & 71.2 & 1548.4 & 19.5 & 5998.6 & 0.003 \\
\hline 2001 & -1423 & -169 & 114.6 & 1459.7 & -17.7 & 6363.7 & -0.003 \\
\hline 2002 & -1227.1 & -71.4 & 48.9 & 1605.3 & 355.7 & 6794 & 0.052 \\
\hline 2003 & -1415.3 & -100 & 92.1 & 2273 & 849.8 & 7228.8 & 0.118 \\
\hline 2004 & -2395.1 & -21.4 & 164 & 2280.2 & 27.7 & 8090.7 & 0.003 \\
\hline 2005 & -3556.3 & -91.9 & 182.6 & 1855 & -1610.6 & 8925.4 & -0.18 \\
\hline 2006 & -3584.7 & 18.6 & 257.8 & 2084.5 & -1223.8 & 10675.4 & -0.115 \\
\hline 2007 & -4574.2 & 98.4 & 408.2 & 2029.6 & -2038 & 12131.4 & -0.168 \\
\hline 2008 & -5084.4 & 451.1 & 292.1 & 2884 & -1457.2 & 15593.4 & -0.093 \\
\hline 2009 & -4448.8 & 616.6 & 266.6 & 2682.7 & -882.9 & 16912.2 & -0.052 \\
\hline 2010 & -4823.8 & 926.2 & -152.4 & 2713.7 & -1336.3 & 18762 & -0.071 \\
\hline 2011 & -6261.7 & 896 & -187.8 & 3454.7 & -2098.8 & 20476.6 & -0.102 \\
\hline
\end{tabular}




\begin{tabular}{llllllll}
\hline 2012 & -7486.6 & 1332.3 & -275.9 & 3084.9 & -3345.3 & 21965.5 & -0.152 \\
2013 & -8270.1 & 1249.2 & -240.4 & 4813.3 & -2448 & 23851.6 & -0.103 \\
2014 & -8495.6 & 1778.9 & -295.9 & 5160.9 & -1851.7 & 25598.5 & -0.072 \\
2015 & -7336.2 & 1235.9 & -307.1 & 3989.3 & -2418.1 & 26920.1 & -0.09 \\
2016 & -6807.3 & 1035.1 & -216.6 & 3369.6 & -2619.2 & 27829.6 & -0.094 \\
2017 & -7593.2 & 1456 & -146.5 & 3230 & -3053.7 & 28903.4 & -0.106 \\
Average & -3578.1 & 512 & -66.9 & 2155.8 & -977.2 & 12026.5 & -0.067 \\
\hline
\end{tabular}

Source: Central Bank of Jordan.

Table 2. Development of Exports and Imports (1990-2017)

\begin{tabular}{|c|c|c|c|c|}
\hline Years & $\begin{array}{l}\text { Exports(million } \\
\text { JD) }\end{array}$ & $\begin{array}{l}\text { ExportsGrowth } \\
(\%)\end{array}$ & $\begin{array}{l}\text { Imports(million } \\
\text { JD) }\end{array}$ & $\begin{array}{l}\text { ImportsGrowth } \\
(\%)\end{array}$ \\
\hline 1990 & 706.1 & 10.7 & 1714.7 & 40.2 \\
\hline 1991 & 770.7 & 9.2 & 1750.2 & 2.1 \\
\hline 1992 & 829.3 & 7.6 & 2291 & 30.9 \\
\hline 1993 & 864.7 & 4.3 & 2449.9 & 6.9 \\
\hline 1994 & 995.2 & 15.1 & 2357.6 & -3.8 \\
\hline 1995 & 1241.1 & 24.7 & 2588.2 & 9.8 \\
\hline 1996 & 1288.2 & 3.8 & 3041.6 & 17.5 \\
\hline 1997 & 1301.4 & 1 & 2906.5 & -4.4 \\
\hline 1998 & 1277.9 & -1.8 & 2712.4 & -6.7 \\
\hline 1999 & 1298.8 & 1.6 & 2622.5 & -3.3 \\
\hline 2000 & 1346.6 & 3.7 & 2888.3 & 10.1 \\
\hline 2001 & 1626.7 & 20.8 & 3049.7 & 6 \\
\hline 2002 & 1963.9 & 20.7 & 3191 & 4.6 \\
\hline 2003 & 2184.9 & 11.3 & 3600.2 & 12.8 \\
\hline 2004 & 2753 & 26 & 5148.1 & 43 \\
\hline 2005 & 3049.7 & 10.8 & 6606 & 28.3 \\
\hline 2006 & 3689.9 & 21 & 7274.6 & 10.1 \\
\hline 2007 & 4063.6 & 10.1 & 8637.8 & 18.7 \\
\hline 2008 & 5633 & 38.6 & 10717.4 & 24.1 \\
\hline 2009 & 4526.3 & -19.7 & 8975.1 & -16.3 \\
\hline 2010 & 4990.1 & 10.3 & 9813.9 & 9.4 \\
\hline 2011 & 5684.5 & 13.9 & 11946.2 & 21.7 \\
\hline
\end{tabular}




\begin{tabular}{lllll}
\hline 2012 & 5599.5 & -1.5 & 13086.1 & 9.5 \\
2013 & 5617.9 & 0.3 & 13888 & 6.1 \\
2014 & 5953.6 & 6 & 14449.2 & 4 \\
2015 & 5561.4 & -6.6 & 12897.6 & -10.7 \\
2016 & 5359.6 & -3.6 & 12166.9 & -5.7 \\
2017 & 5333.1 & -0.5 & 12926.3 & 6.2 \\
Average & 3054.0 & 8.5 & 6632.0 & 9.7 \\
\hline
\end{tabular}

Source: Central Bank of Jordan.

Table 3. Results of the Augmented Dickey-Fuller test

\begin{tabular}{lll}
\hline Variable & Critical Value $(5 \%)$ & t-statistic \\
\hline $\ln R X$ & -3.61 & -1.35 \\
$\ln R M$ & -3.64 & -2.7 \\
\hline
\end{tabular}

Table 4. Results of the Augmented Dickey-Fuller test (the first difference)

\begin{tabular}{lll}
\hline Variable & Critical Value $(5 \%)$ & t-statistic \\
\hline $\ln R X$ & -3.62 & $*_{-4.38}$ \\
$\ln R M$ & -3.62 & $*_{-3.75}$ \\
\hline
\end{tabular}

Note: * indicates a statistical significance at the level of $5 \%$

Table 5. Results of the Cointegration Test of the Current Account Solvency Equation

\begin{tabular}{lllll}
\hline The null hypothesis & Critical value (5\%) & Trace Statistic & Eigen Value & Prob. \\
\hline There is no cointegration * & 20.26 & 30.56 & 0.68 & 0.0013 \\
There is one vector at most & 9.16 & 8.67 & 0.37 & 0.0619 \\
\hline
\end{tabular}

Note: * indicates that the null hypothesis was rejected at a significance level of 5\%.

\section{Copyrights}

Copyright for this article is retained by the author(s), with first publication rights granted to the journal.

This is an open-access article distributed under the terms and conditions of the Creative Commons Attribution license (http://creativecommons.org/licenses/by/4.0/). 